\title{
Bodies of War: Disabilities and Heroism in the First World War
}

\author{
RHIAN ATKIN \\ Cardiff University
}

\begin{abstract}
In the present article, I analyze discourses of masculinity and the male body associated with Portugal's involvement in World War I. I examine these from three perspectives: the national military body; medical and political discussion of disabled bodies; and soldiers' stories about their own experiences. I draw on the popular press, published memoirs, and government and institutional documents to examine the fluid and shifting accounts of masculinity, disability, and heroism during and just after the war. I argue that representations of heroism in this context are directly linked to the male body; furthermore, they are both variable and constructed to serve specific ideological or personal purposes. More broadly, I conclude that the body in war and disabled by war comes to stand for Portugal's experiences as a nation at the Western Front, and in the process makes invisible the individual bodies of men who fought for their country.
\end{abstract}

Keywords: Military, Corpo Expedicionário Português, masculinity, injury

This article contributes to a growing body of research devoted to the histories of the Portuguese men who fought on the Allied side during the First World War, 1914-18. It explores how masculinity was constructed in various wartime discourses of belligerence and heroism in Portugal. Physical strength and bravery were crucial to conceptions of ideal military masculinity, even though this notion may not accurately reflect individual soldiers' experiences and identities. Possible emasculation through injury or shell shock forced a re-evaluation of 
masculinity, with disabled soldiers being actively reconstructed to become productive again as men and throw off the 'feminizing tendencies of disability' (Bourke 74). 'Masculinity' and 'emasculation' are thus regarded as flexible constructs, the meaning of which shifts according to time, place, and the body to which they are applied. I will examine discourses of the Portuguese wartime male body from three different perspectives: the national military body; medical and political discussion of disabled bodies; and soldiers' stories about their own experiences. I deal with a range of source material from the popular press to personal memoirs and the visual arts to examine the intersections of masculinity with notions of sportsmanship and heroism, particularly in relation to bodies that were disabled in military action. In my analysis of this material, I will show how the specific discourses of heroism were constructed around the bodies of men who fought, and how those bodies came to stand for the nation as a whole.

Bodies, and the treatment of injured bodies, were central to the conception of early consciousness-raising magazines such as $O$ mutilado and A guerra, published by and for veterans in the 1920s. More recently, Portuguese soldiers' lived experience of the Great War is at the forefront of work by Ana Luísa Araújo Pinto, Cláudia Pinto Ribeiro, Fátima Mariano, Sílvia Correia, and Maria José Oliveira. Other scholars, such as Filipe Ribeiro de Meneses, Jorge Pedro Sousa and António Ventura, have turned to an examination of propaganda and press coverage of the war and the 1914-18 period in Portugal. The impact of gender studies on historiography has given rise to a significant body of scholarship analyzing masculinities in periods of War: Joanna Bourke and Julie Anderson foreground disability in their seminal studies, and Ana Carden-Coyne gives an overview of recent work relating to the British experience. This article brings together these strands of scholarship to examine how the popular press in Portugal revealed the real-life experiences of individuals who were the anonymous actors in political events. In the absence of memoirs from a body of soldiers with generally low levels of literacy, newspapers, current affairs magazines, illustrated weeklies, and the comic press provide rich sources of information about men's bodies and how they were used for national and international political purposes (Mariano 529). As this article will reveal, the relationship between masculinity, heroism, and political power changed as it was played out in public and private discussions of the male body and the military body, both during and after the war. 


\section{Sportsmanship and the Military Body}

Men's bodies were spent in the war as though they were a currency with little value: the eventual human cost on all sides reached ten million deaths and twenty million people incapacitated (Strachan 328). Initially, many of the belligerent nations saw the war as sport played out on the battlefields. Neutral Portugal was no different. In the first months of the war, the Lisbon daily A capital began to print regular columns on sport and the war, reflecting the attitude in broader political discussions that war was a game. Initially, it noted how sports were being left without sportsmen as athletes were becoming soldiers (31 August 1914, 3). These columns contributed to the construction of a type of masculinity fit for war: physical strength and fitness, stamina and fearlessness are privileged in public debate as heroic qualities. At the same time, the way in which A capital and other outlets foreground the qualities of sportsmanship in armed combat makes more frivolous the very serious question of war; in this respect, the Portuguese press reflects the presentation of war as a sporting endeavor in the Anglophone world (Aulich and Hewitt 53-55).

The type of masculinity constructed through the language of sportsmanship comes to reflect the health of the nation overall (Cleminson 57-58). Notions of masculinity and virility, athleticism, heroism and vitality were conflated on the Allied side. In the Portuguese press, such as Ilustração portuguesa, the visual impact of Allied deaths was minimized and images of the physical strength of the Allies were juxtaposed with photographs of dead German soldiers (9 November 1914): Allied vitality versus German fragility. In press vehicles in Portugal, and in this first war to be covered by photo-journalists (Sousa 30), visual impressions of strength were crucial, as individual soldiers stand for the body military in general, and in turn for the strength of the nation: the nation's potential for power is constructed by and through the bodies that will fight for it.

Sportsmanship came to represent a specific form of heightened masculinity in the war, with the results of the recklessness of belligerent politicians and officers who showed little concern for the lives of those they commanded, being reconstructed in the press as the extraordinary bravery of individual soldiers. Defrance was promoted to Captain after his first injury. As he was about to return to the battlefield after a third injury, he was described as a hero: "Este Hercules, 'recordman' da resistencia e da coragem, não deseja um minuto de descanso 
enquanto os allemães fizerem a guerra á sua patria!" (A capital, 27 November $1914,3)$. This view masked the unprecedented numbers of lives being lost or destroyed on both sides of the conflict. Furthermore, the precise "heroic" qualities that $A$ capital claimed made these men so well-suited to combat is also revealed, in the facts reported, as offering no protection against the violence of trench warfare, in which sportsmen and peasant workers alike faced horrific conditions. In the first months of the Great War, the injured sporting body is reformulated in A capital as a signifier of courage, strength and heroism, despite the logical inconsistencies of that reporting.

\section{The National Military Body}

Individual national and Allied military bodies were presented in the Portuguese press as masculine and physically strong, in contrast with the emasculated, feeble Germans. In the case of both Germany and Portugal, a single male body came to stand for each nation in the comic press as cartoons looked forward to Portugal's military engagements. With the press subject to censorship, cartoons served the crucial function of making sharp political comment (Ventura 497). Through the figure of the Kaiser, depicted as silly, animalesque or monstrous, the German population was dehumanized, making that country's losses easier to ignore. $O$ $Z e ́$, for example, reduced the Kaiser to the diminutive nickname "o Bigodinho," poking fun at his moustache as a manifestation of empty masculinity (17 September 1914, 1). Miau! routinely suggested that the forthcoming intervention of Portuguese troops in the Allied efforts would soon crush a weak German leader and his army (4 February 1916, 8; 5 May 1916, 4; 5 November 1916, 4$5)$.

Where the plump body of the Kaiser came to symbolize a weak, decadent and even ridiculous Germany, Portugal was often represented in these cartoons by the uncouth man of the people, Zé Povinho (e.g., Miau! 7 April 1916). Like Camões, this popular figure was used to mask Portugal's unpreparedness for war, while the press sought to stir up the moral strength required for military action (Meneses, "Camões"). Just as with the Kaiser, Zé Povinho stands in for the many bodies that had been and would be sent to war, veiling the realities that both Portuguese and colonized men had already experienced in Africa and the horrors 
of trench warfare that would await the Corpo Expedicionário Português (CEP) in Northern Europe.

In photographic journalism, by way of contrast with the comic press, the images of colonized men who supported the Portuguese army in Africa reveal the differentiation between bodies that underlay Portuguese colonial policy of the time (Meneses, "Introduction" 8). Angolan soldiers serving in 1915 in the Portuguese army and pictured in Ilustração portuguesa (29 March 1915, 391) are dressed only insofar as they could be recognized as being attached to the Portuguese military (Sousa 125). If Portuguese soldiers were notoriously underequipped and undernourished (Henriques and Leitão; Marques, Os portugueses; Fraga, Guerra e marginalidade; Pinto; Oliveira), these colonized men were left out of Eurocentric histories almost altogether until recently (Arrifes; Meneses, "O Império"; Pires). The injuries and deaths of colonized soldiers do not consistently appear in the official figures of Germany or Portugal, and the racism inherent in the colonial system ensured that they and their families received little, if any, support or compensation for their efforts on behalf of European colonial powers. The value ascribed to their bodies by the Portuguese state was less than that ascribed to European Portuguese soldiers, and their stories as individuals remain absent from scholarship. As Freire's study reveals, the Portuguese military even seemed surprised when conscripted Maconde men in Mozambique disobeyed military orders (125). Although occasional lone voices such as Manuel Simões Alberto called for a fuller recognition of black comrades' contribution to combat German expansionism, there remains an urgent need for further scholarship about these soldiers and due incorporation of their contribution into histories of the war. Their bodies are present in these images but absent from discussions about the national military body, as most studies focus on the CEP and its engagement at the Western Front.

The idea of the national military body is contained explicitly in the name of the Corpo Expedicionário Português. If the army can be read as a single, military body, then metaphors of sickness, lack of fitness and disablement are obvious when we consider the history of the CEP's involvement at the Western Front. Following Germany's declaration of war on Portugal on 9 March 1916, the CEP had to be composed quickly, while officers and soldiers alike were reluctant to intervene in Europe (Henriques and Leitão 12; Pires 98-99). After only brief training, the CEP spent months at the front during the harsh winter of 1917 and 
the exhausted military body was easily defeated by a German offensive at La Lys on the night of 9-10 April 1918 (Henriques and Leitão 32; Correia 37). After hours of battle, the CEP surrendered, and by 10 April, the number of Portuguese prisoners of war had risen from zero to more than five thousand (Cruz Vermelha 6). Recently, Oliveira (34) and Henriques and Leitão (79) have put the figure substantially higher: 6983 losses that night, 6585 of which were POWs. Portugal was left with proportionately more prisoners of war to troops deployed than any other nation (Mariano 527). The Battle of La Lys and Portugal's experience in combat more broadly were a source of deep humiliation for the country (Meneses, "Introduction" 1), and the destruction of the CEP, with its remaining troops subsumed into the British Expeditionary Force, left the Portuguese national military body disabled and emasculated. In the post-war period, disability would come to be crucial to a reconstruction of masculinity as both soldiers and country alike sought to assuage their wounds.

\section{Sickness and Disability}

Portuguese soldiers suffered a high number of illnesses - some already existing, some developed as a result of the conditions during the war. In Mozambique, $20 \%$ of soldiers who made up the first expedition were struck by illness and never entered combat (Castaño 24). The Portuguese government was so keen to send troops to the Western Front that those who enlisted were not properly screened for fitness. The fact that the Allies had an ongoing need for more infantry by this point in the war only exacerbated this problem (Fraga, "Saúde e apoio sanitário" 361). Even before the soldiers reached the Front then, the CEP was a weak, sickly and poorly prepared body (Sousa 22). The conditions of trench warfare and the injuries sustained in combat led to a significant number of incapacitated men, many of whom would suffer long-term and incurable injury and/or illness. Following the battle of La Lys, what remained of the army was, as Augusto Casimiro put it shortly after the war: "[um] mutilado, abandonado e mil vezes negado Corpo Expedicionário Português" (87). As we see from these words, the military body was viewed to have been treated badly - as badly, in fact, as the individuals of which it was composed.

The battle of La Lys left the CEP a largely imprisoned body. The proportion of POWs to deaths was extraordinarily high (Fraga, "La Lys" 418). In fact, an 
examination of the graves in the Portuguese Cemetery in La Rochelle revealed that the majority of deaths in combat — around 60\% — occurred prior to the Battle of La Lys. ${ }^{1}$ Records held at the Military Museum Archive in Lisbon reveal that in many cases the cause of death was illness rather than injury, while Fraga (Guerra e marginalidade 84) reports a total of 46,673 cases of men treated in field and base hospitals for illnesses not caused by gas or wounding in combat. The relatively low number of Portuguese fatalities compared with other belligerent nations raises questions about what happened to those who returned alive from the war. The Portuguese military body was wounded and sick and would need to be treated on its return to Portugal, and soldiers would need to be reintegrated into Portuguese society (Oliveira 127-30).

\section{Public Discourses of Disability}

Official government figures published in 1926 placed the number of men injured and declared unfit for service at 1,535 (A guerra, 1 February 1926, 13). Other estimates of the same period, however, placed the figure much higher, at around 15,000 (A guerra, 1 February 1926, 17). Fraga (Guerra e marginalidade 121) records 5,354 "ferimentos incapacitantes," although in a later study he suggests 2,311 injured and 2,486 gassed in France alone, and he acknowledges that the total figures could be higher ("Saúde e apoio sanitário" 362). The number of illnesses that were contracted - many of which were caused by poor nutrition and the harsh conditions and climate of the trenches - was significant but discounted as part of the inevitable cost of war and ineligible for compensation. The discrepancy between official statistics and unofficial estimates of the numbers of war-disabled veterans reported in 1926 perhaps arose, at least in part, from the educational level and class status of the men who enlisted. Literacy in Portugal during the period was only $17 \%$, and this made it nearly impossible for the majority of veterans to fathom the rules and to collate and present the thirteen

\footnotetext{
${ }^{1}$ I am very grateful to Ysgol Clywedog, Wrexham, and particularly to Clare Temple for enabling an expedition to the Portuguese cemetery in La Rochelle, and to Lowri Allman, Sara Bolas de Almeida, Oliver Brownridge, Ana da Rocha Carvalho, Pedro Miguel Martins de Correia, Bruna Oliveira Drago, Edan Jackson, Megan Maddocks, Charley Owen, Ana Margarida Ribeiro, Pedro Miguel Vidal, and Charlotte Emily Franks for their extraordinary work in examining every gravestone to ascertain the date of death. The trip was funded by the European Parliament and the ESSE project at Cardiff University.
} 
separate documents required for the government committee to assess their level of incapacity and award a pension. Many veterans also complained of the inconsistency of committees and the levels of bureaucracy (A guerra, 1 March 1926, 19). Apart from a study by Ribeiro, those affected remain largely absent from scholarship.

As men with broken bodies returned from the battlefields and prison camps, their treatment and "re-education" became a pressing political issue. Portugal's hospitals and clinics, most of which were charitable institutions, did not have the capacity to treat all the men, many of whom were "returned" to their places of origin (Actas 2, 24 Nov. 1919, 8). Returning soldiers' injuries and missing limbs were visible, living evidence of the government's ineptitude and the army's failure (Anderson 43; Almeida Pinheiro 18). In a period of political turbulence, their bodies were used again as ammunition against the allegedly Germanophile Sidónio Pais (Fraga, Guerra e marginalidade 111), who had come to power in 1917 through a coup. It became apparent quickly after the Armistice in 1918 that Pais's government had no plans in place for the repatriation and any necessary treatment of the thousands of servicemen stationed or imprisoned overseas. As Robert McRuer observes, states often see a need to "manage" disability as a national issue (172). After the war, the question of how Portugal would "manage" its disabled veterans was urgent. At this point, José Pontes, along with his colleagues Tovar de Lemos and Aurélio Ferreira, come to the fore as key lobbyists in the debate around the disabled men, in the press and in the political sphere alike.

\section{Support, Treatment and Rehabilitation for Disabled Soldiers}

The lived reality of men who sustained injuries in combat or whose health deteriorated as a result of the Portuguese state's neglect of its soldiers in the

trenches and in POW camps is an image largely absent from the mainstream newspapers, illustrated weeklies, and cartoon press. The management and rehabilitation of soldiers was nonetheless a pressing issue. Pontes, Ferreira, and Lemos wrote newspaper columns, sat on and appeared before government committees and attended conferences, representing Portugal nationally and internationally as spokesmen for those disabled and invalided in the war (Correia 39). They seem to have been self-appointed, achieving their positions of 
influence through their personal connections, lobbying, and the apparent friendship between them. Arguably, without them, the government may have ignored the plight of the wounded altogether; but their attitude toward the men for whom they spoke, and whom they treated, was consistently paternalistic and deeply conservative. In practice, Pontes, Ferreira, and Lemos did little to redress the social inequality that existed well before the war or to improve conditions generally for former soldiers upon their return to Portugal.

Dr. José Pontes had been concerned with a link between the able physical body and good moral health since his involvement in the sports movement and early sports journalism of the 1910s. Although no byline is given, he may well have been the author of the aforementioned columns on sport and war published in A capital. From 1917, he became a vocal promoter of rights for and discussion of those left injured or disabled by the war. Indeed, the extent of his influence on public debate on the subject was such that newspapers changed their terminology for the wounded from feridos to mutilados da guerra (the latter term having a greater sense of permanency or long-termism). In his columns on rehabilitation for A capital (published as a collection in 1918), Pontes detailed the injuries of individual soldiers. Pontes' aim was twofold: to promote Ferreira's work in rehabilitating the men deemed useless after injury; and to appeal to the public to support the Instituto de Arroios (Ribeiro 326). He explains that many returning mutilados were unhappy about being interned, in part because they thought they could not be cured, and also because they did not want to be subject to orders again. For Pontes, their attitude made moral/emotional treatment a priority: "A questão resolvia-se, pois e principalmente, a fazer o 'penso moral' antes do tratamento financial e profissional. Era absolutamente necessario" (Pontes 8). Moral/emotional health, in Pontes's view, went hand in hand with physical health, and values of masculinity for wounded soldiers were recast in this light.

\section{Stories of Heroism and Disability: José Pontes}

The examples abound of men whose heroism is recoded after disability. For example, Pontes describes "o bravo soldado Sequeira," the first Portuguese soldier to be blinded in the war, as "um bravo, um authentico heroe" (17). Sequeira's patriotism is explicitly linked in the narrative to his heroism in combat and to his coming to terms with the permanent injury he sustained: "E hoje, 
impossibilitado de combater, é sempre um portuguez de grande alma e um sonhador de glorias para a sua terra. Quando fala, illumina-se dizendo que tudo quanto é portuguez é melhor" (Pontes 17). Notably, "terra" here, as used by Pontes, refers to Portugal as a nation rather than the man's home region, as is the tendency for soldiers who wrote memoirs, such as António Pereira dos Santos.

Pontes seeks to make the former fisherman sound as physically "normal" as possible, observing his agility and intelligence in mending nets. Part of Sequeira's heroism rests in not appearing wounded: "E o Sequeira, erguendo a cabeça na direcção do camarada que o interrrompia, dava o aspecto de que os seus olhos se ficavam sobre elle" (19). Such apparent normality despite serious injury is connected with the man's earlier heroism in combat when, having lost his right eye, "o bravo rapaz manteve-se no seu posto ainda uma hora! A sua espingarda fez constantemente fogo!" (Pontes 21). Sequeira's ability to stay calm and stay at his post despite having been blinded is implicitly linked to his ability to mend fishing nets and return to the manual work of his pre-war life. His blindness cannot be cured, and so heroism now resides in restoring a semblance of normality. A similar structure is repeated in most of the stories: Pontes describes the soldier's heroism that led to him sustaining an injury before detailing his recovery and new occupation. Every time, heroism in combat involves ignoring the injury sustained, while heroism in recovery is tied to ignoring or overcoming the injury without a cure or use of prosthetics.

The heroism that Pontes ascribes to individual soldiers is an important counter to the feelings of emasculation that Portugal and its army suffered at a national level after La Lys. Each of the men he describes is, we are told, the bravest of his battalion, heroic in his actions. For example, Primeiro Cabo Pinho da Graça was promoted for acts of courage and showed the heroic quality of honesty even before he was injured (Pontes 11). In another case, Nuno Robalo, who had the chance to escape conscription but did not take it, is proud to have kept his honor despite losing an arm (Pontes 33-34). Although his injury is emasculating because he cannot earn his living, the soldier is redeemed and revalidated as a man by his commitment to rehabilitation and through realizing the potential for some form of paid employment once he leaves the hospital. Key to these individual stories of redemption are Pontes, his colleague Aurélio Ferreira, and the Institute's staff, who collectively act as guardians and spokesmen for the mutilados, enabling them to reclaim physical control of their 
bodies - and all the better if this could be done without prosthetic limbs, for it was unclear how these would be supplied and paid for (Actas 4-5 Dec. 1919, 10203). Physical rehabilitation is thus viewed as personal empowerment and the revalidation of injured former soldiers as socially useful men (Ribeiro 326-27; Pontes 23-24, 30).

In Pontes' stories, loss of a limb is reduced to the status of a graze. For example, Nuno Robalo, who learns to peel potatoes without a prosthetic arm, is able to do so faster than a comrade who was not wounded (Pontes 29). Even when put to work on feminine-coded tasks such as preparing vegetables, the men's rejection of prosthetics (always voluntary, of course) is a sign of their continued masculinity, making them even super-men: "Não resta dúvida—diz o nosso colega [ao ver os talentos do Soldado Robalo]-Este rapaz serve de argumento para a defeza d'aquella these de que não é necessario o apparelho quando a profissão é bem escolhida para o mutilado" (Pontes 30). Notably, the focus here is on medical professionals choosing an "appropriate" new job for the injured man: the paternalism is obvious, and the amount of agency allowed to the wounded is limited. Stories such as these, as well as photographs of the wounded recovering well served to pacify concerned readers and supported the idea that these men would once again be useful members of society (Sousa 379). Work is both a sign of honesty and removes the need for long-term additional support. Pontes's columns, which present the mutilados as self-sufficient, implicitly reject the notion of long-term government support for those wounded in the service of the nation. This was very helpful for a government on the verge of bankruptcy.

\section{State Policy for Disabled Soldiers}

Pontes's column effectively justifies the state's negligence of its obligations: his benevolent paternalism towards disabled soldiers and lauding of their rehabilitation without prosthetics placed a mask over the country's initial incompetence in treating its wounded. Anderson observes how World War One brought disability into public view on a grand scale, highlighting the importance of charitable giving to support those disabled in the War (7-8). Charitable associations, many founded and run by women, had been central to support for Portuguese soldiers from even before the country's official entry into the war. By 1918, charitable facilities such as the Arroios Institute and the Instituto 
Clínico da Cruzada das Mulheres Portuguesas would be requisitioned by the government (Decreto $N^{\circ}$. 3.732: 2 January 1918). Aurélio Ferreira's Instituto de Reeducação dos Mutilados da Guerra at Arroios, a mix of school and hospital staffed almost entirely by women (Gomes 518), was the only one to offer a program of educational support to injured and mutilated men (Pinheiro 18). ${ }^{2}$ The institute sought to "empower" the wounded and disabled to earn a living, removing the need for support from the (financially dysfunctional) state, from which resources were not forthcoming (Ribeiro 319, 322). The Institute's activities were based to some extent on the recommendations of the Inter-Allied Conference for the Study of Professional Re-education in Paris, which Ferreira and Tovar de Lemos had attended in 1917:

1. Where possible, to maintain a wounded veteran in his original region and employment;

2. To offer financial and other incentives to motivate reintegration;

3. To guarantee a pension or provide suitable compensation where a disabled soldier chooses a new profession;

4. To maintain veterans in institutions only for so long as absolutely necessary, to enable them to re-enter the workforce and to avoid them becoming institutionalized. (Gomes 518)

While the war continued, Portugal did not adhere to this code of practice. Sidónio Pais used the publication of leis para os mutilados to boost his own popularity in 1918 (Ribeiro 329); however, the state's commitment to its mutilados was only properly formulated in 1921, very late when compared with Britain, which legislated in 1916 (Anderson 45-46). In practice, mutilados were first sent back to the barracks or training schools from which they had originally come, and this was disastrous for the morale of both able-bodied and disabled soldiers. The policy was soon changed and injured soldiers were sent to a hospital for recovery - more often than not in Lisbon (Gomes 518). There, efforts would be made to convince the soldier that he was not useless, although "re-education" was voluntary. From the hospital, he would be transferred to the Institute at Santa

\footnotetext{
${ }^{2}$ See Correia for a more detailed description of the Instituto's activities.
} 
Isabel (until this returned to its normal functions in 1919), or to the Instituto de Reeducação dos Mutilados da Guerra in Arroios.

The Institutos de Santa Isabel and Arroios were Ferreira's pioneering project and formed part of a broader European movement for the treatment of men disabled by the war (Ribeiro 316). As in Britain, institutions were intended to support mutilated soldiers and assist them in renegotiating their masculine identity (Anderson 43). On the one hand, the institutionalized men were almost certainly better nursed and cared for by the professionally trained women who supported their rehabilitation than they would have been anywhere else in Portugal, at least in purely material terms. On the other hand, the paternalistic approach to their "re-education" and "re-validation" (the terms used in Portuguese) and their submission to a group of women and men of a higher social class who would now decide what was good for them for the rest of their lives must have left men feeling disempowered for it denied them their agency (Correia 41). In addition to the physical and professional rehabilitation of the wounded, Ferreira also sought to improve their moral character (Ribeiro 320), a clear betrayal of the fact that Ferreira's undoubtedly worthy intentions were counteracted by his patrician disdain for the ordinary men who were the objects of his apparent concern. Meanwhile, the serranos's wives were apparently trained and sent out to work (Osório 87). The failure of the Institute to restore these men to working life was noted as early as 1919 by its director, Tovar de Lemos (Actas, 24 November 1919, 8-9), who commented on men fleeing the Institute and taking to the streets to beg. Indeed, if a report on the Arroios Institute from an inspection committee is to be believed, "falhou completamente como estabelecimento de reeducação," because it did not teach new skills but only new ways of doing the tasks the men already knew (Gomes 519). It appears that, for the most part, those who already had work before the war were returned to it, while those who had no work were left with nothing. The Institute's own statistics and reports deferred blame to the disabled, observing that they wanted to return to their families or seek remunerated employment rather than being put to work at menial tasks in return for a pension (Gomes 519; Ribeiro 330). This provides proof, surely, that personal agency was crucial to these men as they recovered from their experiences in the war. It is perhaps because of its failure that the Instituto de Reeducação dos Mutilados de Guerra (which had been had been requisitioned by the State in 1918 [Decree 3.732, 2 January 1918]), was given 
back to the charitable Cruzada das Mulheres Portuguesas in 1920 with a promise of assistance from minor military personnel as long as mutilados de guerra were treated there (Law 959, 7 March 1920).

State support for wounded soldiers was not sufficient on a large scale. While Pontes, Lemos, and Ferreira sought to speak for injured soldiers in the mainstream press and in interminable, indecisive government committees, they were not always working in the best interests of these men in practice. As Correia observes, when statistics suggest around 7,000 wounded men, it is incongruous that only 1,759 were officially recognized as disabled (Correia 36). The statistics are, at the very least, variable and often contradictory. Lemos also seems to have been quite opposed to "re-education" that implied learning to read or improving a man's social situation, seeing such desires as exploiting the system: "a situação do mutilado neste instituto é boa e [...] alguns deles esploram esta situação" (Actas 2, 24 November 1919, 9). He thus proposed limiting support for mutilados to a maximum of one year (10). Physical rehabilitation was implicitly tied up with the class warfare that had come to the fore internationally in the period. As such, and although they were largely unconsulted by the bourgeois men making decisions about them in policy fora, soldiers themselves organized to support one another and raise public awareness of their post-combat needs.

\section{Soldiers' Stories: The Liga dos Combatentes}

Most soldiers taken prisoner in the war had suffered serious neglect, which led to illness and malnutrition, as a photograph in A guerra so starkly shows (May 1928, 4). Neither Portugal nor Great Britain (as the commanding army) had provided for their needs, and many had relied on the generosity of better-fed French prisoners to survive (Santos cxvii; Mariano 530). When they finally returned, the former soldiers pressured the government for assistance and, in 1921, the Liga dos Combatentes da Grande Guerra was founded as a lobbying group and support network (Gomes 519). ${ }^{3}$ One of the group's first acts was to erect an enormous monument at La Couture in France to honor the soldiers who had been stationed there during the war. On the front of the statue, a soldier fights

\footnotetext{
${ }^{3}$ Henriques and Leitão claim that this took place in 1919 (90).
} 
off death to save the Republic, which is standing behind him, a gesture that places the infantry soldier at the center of the idea of the nation and its glory.

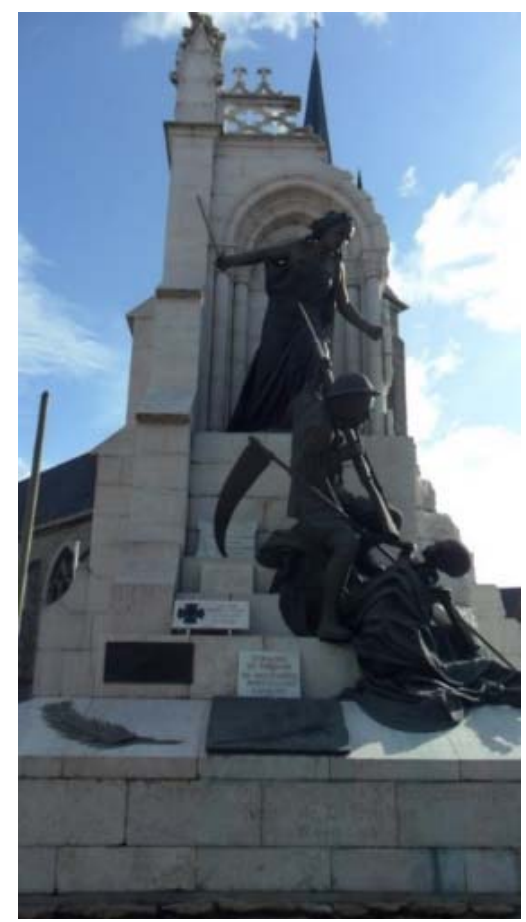

Portuguese Monument to the Soldiers of World War One La Couture (France) (photograph by Rhian Atkin)

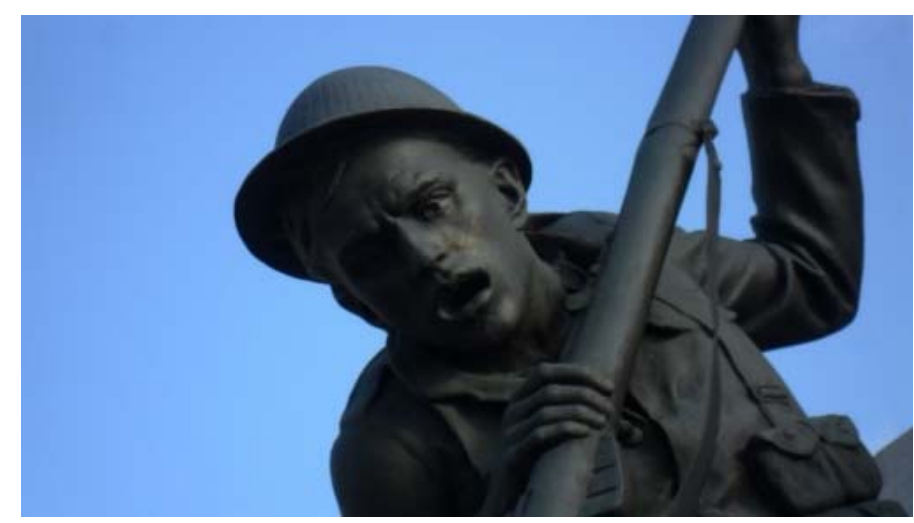

Detail from Portuguese Monument to the Soldiers of World War One La Couture (France) (photograph by Rhian Atkin) 
The statue is a single body erected to represent a host of other bodies, some broken, others killed, but all made whole for the sake of posterity. The bodies of the soldier and the Republic are positioned on and in the sculpted structure of a semi-destroyed church. The monument is in turn placed in front of the actual village church and thus works with its setting to suggest the post-war rebuilding of what had been destroyed. At the rear of the monument, there is a copy of Camões's Os Lusíadas, which suggests that this is not meant to be the church of La Couture but rather the church as a vessel in which Portuguese values are held. The iconography of the monument (and others that came to be erected in towns and cities across Portugal) shows a close and mutual emotional relationship between soldier and state, a statement that is far removed from the actual experience of soldiers. As a site of memory, the whole, able body of the soldier masks the lived experience of specific soldiers who were wounded. Many if not most of the soldiers found themselves abandoned by the state on their return to Portugal, and they were often forced to live in misery and poverty, with whole families inhabiting single rooms (Pinto 105). As such, the monument also functions as a reminder of the physical destruction that occurred, even if most other signs of the war have gone. The number of marble plaques commemorating visits by groups of former soldiers and emigrants is a testament to the use of the monument as a site of memory up to the present day.

The war-wounded of 1917-18 may have received some support, not least for the most urgent medical treatment, but many of those made ill by trench conditions or gas poisoning received nothing (Pinto 106), and tubercular patients had to pay for their treatment (Actas 2: 24 November 1919, 15). As government commissions delayed decisions for over a year with their discussion of whether and how much injured men should receive in pensions, and as public debates around military spending grew heated (Costa 37), many were driven to beg in the streets for sustenance. Although an emergency decree made provision for mutilados under treatment to receive the same pay as they would in active service, many were left waiting for the money to arrive (decree 4.154, 20 April 1918; Actas: 24 November 1919, 89). By 1926, the Liga dos Combatentes established the magazine A guerra to give voice to those who felt they were not being heard. 


\section{A guerra: The Voice of a Collective Body of Soldiers}

Eduardo de Faria makes it clear in the August 1928 issue of A guerra that the situation for former soldiers was desperate: “eles, os pobres mutilados da Grande Guerra, continuam a lutar com a fome, com as dificuldades da vida e a esperarem um D. Sebastião que apareça numa manhã nevoenta e ponha a sua assinatura n'uma lei que os satisfaça, numa lei que dê a César o que é de César, sem sofismas, sem lapsos, sem ingratidões" (13). Faria's words underline the reality for veterans who were left without support and entirely at the mercy of the state. A guerra aimed to raise awareness among the general public about veterans' situation, and while its content praised the medical interventions of Pontes and Ferreira, it also contradicted the happy, healthy heroism they proffered to the public in the pages of A capital. Poems and prose texts published in A guerra almost always presented the disabled soldier as forgotten, marginalized, and dismissed by society. For example, Alfredo Barata da Rocha's poem "Mutilado" notes how: "Quási ninguem repara, soldadinho / Quando tu passas, lento, a coxear" (A guerra, 1 May 1926, 6). Equally, in "A herança do mutilado," by Silva Tavares, the veteran who has lost a limb becomes useless; the joy he felt on returning to Portugal is displaced by his lack of activity; and his disability is viewed as the horrific embodiment of a violent past that his compatriots prefer to forget (A guerra, 1 March 1926, 1). In Tavares's poem, there is no heroism inherent in the disabled body - rather, the mutilated soldier is left with no social function, emasculated and depressed, with little comfort to be derived from the Cruz da Guerra that he won for bravery: "Trabalhador rural, / Sem o braço esquerdo, outr'ora ousado, / - era um inutil dentro da casa! [...] / Este não fazer nada; esta inação / em que me encontro desde que voltei; / esta morte a minarme o coração, / — são bens que, p'ra deixar-te, conquistei" (1). The voice of the disabled soldier speaking to his son highlights the ongoing heroic condition of the soldiers constructed in the period immediately following the war. It appears to begin in the same narrative form as Pontes's columns and highlights the mutilado as "aquele que ao partir mais animou / o espirito quebrado dos rapazes." Unlike Pontes's stories, though, the fleeting acknowledgement of the bravery required to face trench warfare and resist a prolonged attack soon gives way in public reactions to fear or disgust at the mutilated body - a paradox also acknowledged by Correia (51). The father, disabled by war, cannot provide for 
his son because he is unable to work. His situation reveals how the state they had served left soldiers physically, psychologically, and economically broken after the war. In this light, the efforts of Ferreira and others to keep the mutilados in institutions may have been, at least to some extent, an attempt to hide their disturbing, broken bodies away from public view (Ribeiro 325). The poem is accompanied by a line drawing of a man in uniform with one arm missing and the other holding up the Portuguese flag, and it is one of the most explicit images of disability in the magazine. Elsewhere, photographs of actual soldiers more often reveal only the head and shoulders, with a textual description of the injury or disability sustained (9 April 1926, 22). Even in the magazine established by and for former servicemen, there seems to have been a reluctance to show visually the effects of war.

The poems and reports about disabled soldiers form part of a political lobbying campaign as well as acts of solidarity amongst soldiers. Correia notes the complaints about legal provision - or the lack of it - in another magazine, $O$ mutilado da guerra (40). ${ }^{4}$ Despite the bodies of these soldiers having been taken as the premise for multiple fundraising efforts in 1917-18 (Ribeiro 323-24), then, there is little evidence available to suggest that the money raised ever reached the neediest soldiers directly - although much may well have been used to fund the Instituto de Arroios and other hospitals and charitable institutions. Indeed, Santos (clxv-clxviii) was clearly angry that the Cruzada das Mulheres Portuguesas and the government did little to support soldiers during imprisonment and repatriation. Furthermore, for the majority of men, their low level of education and lack of understanding of the bureaucratic state system would have meant that they were unable to access the pension funding that would eventually become available (see Correia 40-41). Even the Liga dos Combatentes, while it raised awareness of their plight, may well have been inaccessible to those from a lower social class in contrast to the officers who established the Liga.

\section{Invisible Bodies: Individual Stories}

The story of the serranos who fought for Portugal and the allied nations on the Western Front is a story of relative invisibility (Correia 47-48). The few first-

\footnotetext{
${ }^{4}$ Unfortunately I have been unable to gain access to this magazine.
} 
hand accounts available to us are so harrowing that to research them requires significant emotional resilience. Many of those fighting were rural manual workers with little sense of what or who they were fighting for and insufficient literacy to record their experiences. Certainly, an articulate notion of the reasons for the war is largely absent from Santos's powerful narrative, in which he records his frequent fear of death and his difficulties with the cold, hunger, fleas, muck, and sleep deprivation that he experienced at the front. For this soldier, a desire to see his beloved family again and to return to his terra sustained him through war and imprisonment. When Portugal joined the war, rural regions remained relatively isolated from the communications of the cities, as one sees in Jorge Brum do Canto's film João Ratão (1940). In other cases, the army simply failed to communicate with families, as is apparent in the story of António Coelho, Soldier 22214. According to his great-granddaughter, Coelho's family members were in mourning for him and his brother, having heard about the battle of La Lys in the news, and therefore they were very happily surprised when the two reappeared in their village some months later, still wearing their army fatigues (Melo).

Despite being called to join the national military body, notions of the national, and certainly of the international, did not mean to Portugal's soldiers and their families what they mean today. As Santos writes in his war diary, his father did not really understand that his son might not return from the Front (xiv). Overall, the experiences of individual injured men went largely unrecorded, and what remains today is only what was photographed or written down: government and hospital records, the body of texts and images produced by those with sufficient literacy and a notion of historical record, and the writings of doctors and journalists who witnessed the effects of the destruction of war. The bodies and voices of those who fought are in large part absent from the discussions of how they should be handled after the war. As Faria observed in 1930, it was those men who, in most cases, did not serve the nation in combat who would, during and after the war, decide the fate of the less formally educated, less fortunate soldiers whose bodies were wasted by the violence (7). In this view, masculinity is a class-based concept with "soldier" (combatente) being separate from "man" (homem). Furthermore, it was those in command, or those who would direct public policy and take charge of the treatment and rehabilitation of men who would claim the space of heroism in public discourse, for their names and not 
those of the men affected (mutilados and those who escaped injury) are more frequently recorded and repeated.

\section{Conclusion}

In 1917-18, both the military body of the CEP and the bodies of individual soldiers came to represent the nation in shifting and fluid ways. Both were widely used in an abstract sense to drive political discourse, initiatives and policy. In the early stage of the war, the mass of serranos who would come to be conscripted were represented by the cartoon figure Zé Povinho, who represents a masculinity rooted in crude or brute force. Zé Povinho is simultaneously the embodiment of Portugal's desires for greatness and glory and a lampooning of the reality of the country's peasant workers who were unfit and unprepared for military service. Following the Battle of La Lys, the dispersed, broken and demoralized bodies of men who had fought became emblematic of the humiliation of the CEP and the nation, and a means of revealing the failure of successive Republican governments. The bodies of the mutilados became just another problem to be addressed and were treated in policy as a homogenous mass.

Individual stories were used to promote the work and ambition of Ferreira, Lemos and Pontes. As self-appointed guardians of public morals, these doctors equated moral strength with physical strength, diverted policy away from the consistent provision of prosthetics, and - on purpose or in effect—denied men who had sacrificed their health the right to improve their learning and prospects. The paternalism inherent in Ferreira's and Pontes' decision-making about these men's future employment effectively removed their conditions and disabilities from public view and silenced their demands for a path out of poverty. By speaking for the men in contexts ranging from the popular press to international policy fora, the doctors stopped the serranos's voices from being heard while constructing themselves as heroic saviors of these injured bodies. Even the press outlets and monuments that were established by the Liga dos Combatentes to raise awareness of the soldiers' experiences and to offer solidarity would have been beyond the reach of most serranos, whether because of the geographical distance of monuments which privileged the dead, or because of the low levels of literacy among rural populations which meant that they simply could not easily access written texts. 
The stories of the soldiers who were injured in the First World War are stories of bodies made invisible. As I have shown, accounts of the Portuguese experience of war - at a national and individual level - are subject to significant variation, reflecting and underlining the reality that there was no single or standard experience for the soldiers who fought, although what any two individuals lived through may have had many commonalities. The construction of 'heroism' in newspapers and other press vehicles must, then, be understood in this context: whether they are aimed at building support for intervention (as in the period before 1916); keeping up the morale of injured men, frontline troops and the general public (such as in Pontes' column); or lobbying for due recognition and recompense (as was the function of A guerra), discourses of heroism are constructed in specific ways for the specific purposes that are most urgent for a particular group at a given point in time. By contrast, the stoical levels of endurance of those who fought are linked to a different set of values that see the man not as a violent machine of warfare who is unblinkingly loyal to an abstract notion of pátria, but as a crucial member of an intergenerational family unit. Endurance, therefore, was necessary in order to return not to the homeland (pátria), but simply home (à terra). In the words of António Pereira dos Santos:

No dia 22 pela manhã segui mesmo apé, chegando á minha querida térra; por vóltas do meio dia, abracei o meu querido páe, e querida mãe, e queridos mânos e mânas e toda a gente que estáva esperando pela minha alégre chegada.

Desde o dia em que sahi para a grande Guérra, até ao regresso de 22 de fevreiro que cheguei á terra, demorei 18 mezes; e bastante que me custou cumprir o dever de soldádo. (ccxi)

\section{Works Cited}

Alberto, Manuel Simões. "O dia do soldado.” A guerra, November 1927, p. 4. Anderson, Julie. War, Disability and Rehabilitation in Britain: 'Soul of a Nation.' Manchester UP, 2011.

Arrifes, Marco Fortunato. A primeira grande guerra na África portuguesa: Angola e Moçambique (1914-1918). Cosmos, 2004. 
Aulich, Jim, and John Hewitt. Seduction or Instruction: First World War Posters in Britain and Europe. Manchester UP, 2007.

Bourke, Joanna, Dismembering the Male: Men's Bodies, Britain and the Great War. Reaktion, 1996.

Carden-Coyne, Ana. "Masculinity and the Wounds of the First World War: A Centenary Reflection." Revue Française de Civilisation Brittanique [Online], XX-1, 2015, www.rfcb.revues.org/305.

Casimiro, Augusto. Sidónio Pais (algumas notas sobre a intervenção de Portugal na grande guerra). Chardron/ Lello \& Irmão, 1919.

Castaño, Daniel. "Notas e enquadramento histórico." João Ninguém: soldado da grande guerra by Capitão Menezes Ferreira, Bertrand, 2014, pp. 7-52.

Cleminson, Richard. Catholicism, Race and Empire: Eugenics in Portugal, 1900-1950. Central European UP, 2014.

Comissão de Estudo das Condições de Reforma e Pensões Temporárias e Assistência a fornecer aos Mutilados da Guerra. Actas das sessões, vol. 2, no. 23, 21 October 1919; 24 November 1919.

Correia, Sílvia. "The Mutilated Face of World War I in Portugal." E-Journal of Portuguese History, vol. 15, no. 1, 2017, pp. 35-54. www.brown.edu/Departments/Portuguese Brazilian_Studies/ejph/html/issue29/pdf/v15n1a03.pdf.

Costa, General Gomes da. “Organisação militar.” Seara Nova, 5 November 1921, pp. 37-38.

Cruz Vermelha, Relatório da gerência da sociedade portuguesa da Cruz Vermelha referente ao ano de 1918. Casa Portuguesa, 1920.

Decree 3.372. Ordem do Exército, 1. 1'a série, 2 January 1918, pp. 5-6.

Decree 4.154. Ordem do Exército, 1. 1ª série, 20 April 1918, no. 5.3.

Faria, Eduardo de. "Os mutilados." A guerra, August 1928, p. 13.

—. "O que nos ficou da guerra." A guerra, March 1930, p. 7.

Fraga, Luís Aires de. "Saúde e apoio sanitário: salvar vidas!" Portugal e a grande guerra, 1914-1918, edited by Aniceto Afonso and Carlos de Matos Gomes, Verso da História, 2013, pp. 359-62.

- Guerra e marginalidade: a comportamento das tropas portuguesas em França, 1917-1918. Prefácio, 2003. 
—. "La Lys: a batalha portuguesa." Portugal e a grande guerra, 1914-1918, edited by Aniceto Afonso and Carlos de Matos Gomes. Verso da História, 2013, pp. 404-18.

Freire, João. Portugal face à Grande Guerra em 1914-1915. Colibri, 2014.

Gomes, Nuno de Santa Clara. "Mutilados: a face incómoda da guerra." Portugal e a grande guerra, 1914-1918, edited by Aniceto Afonso and Carlos de Matos Gomes, Verso da História, 2013, pp. 516-19.

Henriques, Mendo Castro, and António Rosas Leitão. La Lys 1918: os soldados desconhecidos. Prefácio, 2001.

Lei 959. Ordem do Exército, 4, $1^{\text {a }}$ série, 7 March 1920, pp. 208-09.

Mariano, Fátima. "Os esquecidos da guerra: o apoio das mulheres aos

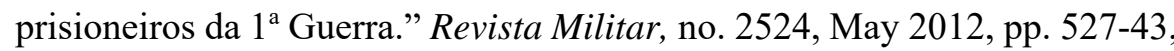
www.revistamilitar.pt/artigo/699.

Marques, Isabel Pestana. Os portugueses nas trincheiras: um quotidiano de guerra. Comissão Portuguesa de História Militar, 2002.

—. "Notas de abertura." De Chaves a Copenhaga: a saga de um combatente, edited by António Pereira dos Santos, Prefácio, 2008, pp. 11-16.

McRuer, Robert. "Disability Nationalism in Crip Times." Journal of Literary and Cultural Disability Studies, vol. 4, no. 2, 2010, pp. 163-78.

Melo, Daniela. Personal interview. May 12017.

Meneses, Filipe Ribeiro de. "Camões, Portuguese War Propaganda, and the Dream of a Safe Colonial Empire, 1914-1918." National U of Ireland Maynooth, no. 12, 2005, pp. 1-27.

—. "O império português." Impérios em guerra (1911-1923), edited by Robert Gerwarth and Greg Menela, Dom Quixote, 2014, pp. 331-60.

—. "Introduction: The Lusophone World at War, 1914-1918, and Beyond." EJournal of Portuguese History, vol. 15, no.1, 2017, pp.1-14. www.brown.edu/Departments/

Portuguese_Brazilian_Studies/ejph/html/issue29/pdf/v15n1a01.pdf.

Oliveira, Maria José. Prisoneiros portugueses da primeira guerra mundial: frente europeia - 1917/1918. Saída de Emergência, 2017.

Osório, Ana de Castro. De como portugal foi chamado à guerra: história para crianças. 2nd ed., Para as Crianças, 1919.

Pinheiro, Frederico d'Almeida. "Mutilados e inválidos." A guerra, August 1929, pp. 18-19. 
Pinto, Ana Luísa Araújo. Memória de um dever cumprido: Portugal na primeira grande guerra. Liga dos Combatentes, 1996.

Pires, Ana Paula. "The First World War in Portuguese East Africa: Civilian and Military Encounters in the Indian Ocean.” E-Journal of Portuguese History, vol. 15 , no. 1, 2017, pp. 82-104.

Pontes, José. Mutilados portugueses: narrativas de guerra e estudos de reeducação. Guimarães, 1918.

Ribeiro, Cláudia Pinto. "Os heróis que a guerra invalidou... reeducar o soldado no Instituto de Mutilados de Santa Isabel (1917-1921)." Revista da Faculdade de Letras: História, vol. 3, no. 9, 2008, pp. 315-35.

Santos, António Pereira dos. De Chaves a Copenhaga: a saga de um combatente. Prefácio, 2008.

Sousa, Jorge Pedro. A grande guerra: uma crónica visual - Parte I. Média XXI, 2013.

Strachan, Hew. The First World War: A New Illustrated History. Pocket, 2006.

Ventura, António. "A guerra e a imprensa portuguesa." Portugal e a grande guerra, 1914-1918, edited by Aniceto Afonso and Carlos de Matos Gomes, Verso da História, 2013, pp. 497-503. 